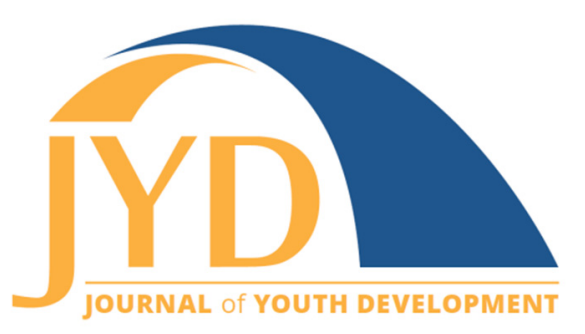

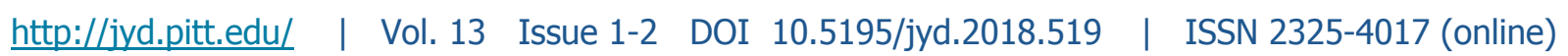

\title{
The Role of Camp in Shaping College Readiness and Building a Pathway to the Future for Camp Alumni
}

\author{
Anja Whittington \\ Radford University \\ awhittington@radford.edu
}

Barry A. Garst

Clemson University

bgarst@clemson.edu

\begin{abstract}
The purpose of this study was to examine whether attending camp promotes college readiness skills in camp alumni. A sample of 420 participants retrospectively reflected on their camp experience and how it helped them gain college readiness skills through an online survey. Quantitative results suggested that a variety of college readiness skills are impacted by the camp and differ slightly based on male and female respondents. Qualitative analysis indicated that camp influences academic pursuits by inspiring one's academic interest, shaping where one studies, and motivating one to persevere and complete college. Supportive peers and adults within the camp setting influence of all these decisions.
\end{abstract}

Key words: camp, college-readiness skills, retrospective analysis

\section{Introduction}

Research on college readiness suggests several skills youth need prior to attending college beyond academic achievement alone. These skills include (but are not limited to): independence, teamwork, resilience, leadership, perseverance, self-efficacy, communication, problem-solving, self-management, self-regulation, time management and critical thinking skills (Nelson, 2012; Savitz-Romer \& Bouffard, 2012; Tierney \& Sablan, 2014). These skills are often gained and practiced during out-of-school-time experiences such as summer camp.

(cc) EY New articles in this journal are licensed under a Creative Commons Attribution 4.0 License. This journal is published by the University Library System, University of Pittsburgh and is cosponsored by the University of Pittsburgh Press. The Journal of Youth Development is the official peer-reviewed publication of the National Association of Extension 4-H Agents and the National AfterSchool Association. 


\section{Role of Camp in Shaping College Readiness}

The literature suggests a variety of ways camp experiences may positively impact youth development outcomes (e.g., Bialeschki, Henderson, \& James, 2007; Garst, Browne, \& Bialeschki, 2011). For example, several studies have examined how camp impacts a young person's perception of their future opportunities, including workforce preparedness (Digby \& Ferrari, 2007; Duerden et al., 2014; Kirk \& Day, 2011), career choice (Bhattacharyya, Mead, \& Nathaniel, 2011; Garst, Baughman, Whittington, \& Gagnon, 2015), and college aspirations (Bourdeau, Galloway, Arnold, \& Nott, 2014). However, few studies have examined how camp may support college readiness skills as well as impact educational choices later in life (Whittington \& Danhof, 2017). Thus, the purpose of this study was to examine the influence of camp experiences on college readiness from the perspective of camp alumni. Three main questions were addressed:

1. Did camp impact future educational choices, and if so, how?

2. To what extent do camp alumni report having gained college readiness skills at camp?

3. What gender differences, if any, exist in college readiness skills reported by camp alumni?

\section{Literature Review}

\section{College Readiness}

Simply defined, college readiness is a student's level of preparation or capacity to enroll in and complete, without remediation, credit-bearing courses at a postsecondary institution (Arnold, Lu, \& Armstrong, 2012; Conley, 2007 \& 2008). Furthermore, college-ready students must earn passing grades and be able to continue additional coursework to reach their academic goals (Arnold et al., 2012; Conley, 2007 \& 2008). Arnold et al. (2012) suggested that college readiness serves as an umbrella term used to describe the complex, interconnected set of skills, traits, habits and knowledge that students need in order to go to college and be successful.

College success predictors include high school transcripts (Tierney \& Sablan, 2014), grade point averages (Conley, 2007), and standardized test scores (Allen, Robbins, \& Sawyer, 2010: Conley, 2007). Although academic achievement is still used to predict college success and is a positive indicator, other factors are considered important to student success. Researchers agree that college readiness includes a variety of skills beyond academic achievement. For example, Conley $(2010,2014)$ and Conley and French (2014) described four keys to college and career readiness: (a) cognitive strategies that help a student think, (b) content knowledge that helps students know, (c) learning skills and techniques that allow a student to act, and (d) transition 


\section{Role of Camp in Shaping College Readiness}

knowledge and skills that prepare a student to attend college. Others skills recommended for college success include: critical thinking and problem solving (Conley, 2008; Mueller, 2009; Nelson, 2012; Savitz-Romer \& Bouffard, 2012), communication (Conley \& French, 2014; Mueller, 2009; Nelson, 2012), independence (Conley, 2008; Nelson, 2012, Savitz-Romer \& Bouffard, 2012), leadership (Mueller, 2009), persistence/perseverance (Conley 2008 \& 2014; Conley \& French, 2014), teamwork and collaboration (Conley \& French, 2014; Mueller, 2009; Nelson, 2012), time management (Arnold, Lu \& Armstrong, 2012; Conley \& French, 2014; Savitz-Romer \& Bouffard, 2012), self-confidence (Conley \& French, 2014), self-management (Arnold, Lu \& Armstrong, 2012: Conley, 2008; Gaertner, \& McClarty, 2015; Mueller, 2009), and self-regulation (Nelson, 2012; Savitz-Romer \& Bouffard, 2012). Such a diverse set of skills has been identified as necessary for high school graduates to be successful in postsecondary education.

While elementary and secondary schools most often serve as the central provider of college readiness information, emphasis has been placed on the impact out-of-school settings can have on student growth and development while indirectly influencing college readiness. Savitz-Romer and Bouffard (2012) stated, "activities that support going to college, don't necessarily talk about college" (p. 208) but rather provide youth opportunities to develop a host of critical skills, including self-regulation and resilience when faced with challenges. Summer camps represent one such out-of-school setting that supports youth development outside of the traditional classroom.

\section{Gender Differences in College Readiness}

Prior to the 1960 s, $60-65 \%$ of bachelor's degrees were awarded to men, but by 1982 women reached parity with men and in 2004-2005 women received 58\%-60\% of all bachelor's degrees (Buchmann, DiPrete, \& McDaniel 2008; Klevan, Weinberg, \& Middleton, 2016). Understanding why women and men choose to attend or not attend college is complex, as many factors may influence a youth's decision. Some scholars suggest that men have alternative choices such as military service, which is comprised of $85 \%$ men (Buchmann et al., 2008), and that "shifting female premiums on college degrees" (Conger \& Long, 2010) provide a socio-cultural context that encourages women to seek higher education.

Currently, male students are less likely than female students to earn a bachelor's degree (Cogner \& Long, 2010), have higher dropout rates (Buchmann et al., 2008), and earn fewer cumulative credits and lower cumulative grades (Conger \& Long, 2010). The decline in males' 


\section{Role of Camp in Shaping College Readiness}

college attendance, college performance, and completion of a college education led to an examination of what has been labelled the "female advantage" (Cogner \& Long, 2010). Research on the female advantage suggests that women have higher non-cognitive skills than men in areas such as organization, dependability, self-discipline, attentiveness, and seeking help from others (Cogner \& Long, 2010; Riegle-Crumb, 2010). This advantage begins to manifest during primary education, where girls demonstrate more advanced social skills, better classroom behavior (Buchmann et al., 2008), and tend to be more academically engaged (Riegle-Crumb 2010) when compared to boys. Social capital (i.e., personal relationships with friends, parents and other adults) has historically been recognized as a female advantage (Reigle-Crumb, 2010).

Although women are more likely to attend college, they still face numerous challenges (Sax, 2007). Women often lack confidence in their academic abilities (Sax, 2007), experience higher levels of anxiety and depression (Klevan et al., 2016), stress over their financial situation (the average income for female college students is lower than men's), and report lower ratings of emotional and physical health (Sax, 2007). Furthermore, men continue to surpass women in earning a STEM-related degree (Klevan, Weinberg, \& Middleton, 2016), men continue "to outnumber females in the most lucrative areas of study" (Klevan, Weinberg, \& Middleton, 2016, p. 25), attend more elite institutions (Buchmann et al., 2008) and earn more in all areas of employment (Corbett \& Hill, 2012).

\section{Camp Outcomes Associated with College Readiness}

A broad body of literature supports the developmental outcomes of camp experiences for children and adolescents (Bialeschki et al., 2007; Eaton, LaMotte, Gutierrez-Colina, Kardon, \& Blount, 2016; Garst \& Johnson, 2005). Outcomes of camp experiences have most often been investigated from the perspective of the attainment of social-emotional skills (e.g., independence, communication, exploration, self-regulation, confidence, and social competence). Over the past decade interest has increased in better understanding how the camp experience may promote outcomes that contribute to student success beyond high school and into postsecondary educational opportunities as well as career decision-making. In other words, growing interest exists in how camp involvement influences readiness for higher education and/or their future career.

With this interest in mind, some research has attempted to align camp-related outcomes with the $21^{\text {st }}$ Century Skill framework, which defines the competencies young people need in order to 


\section{Role of Camp in Shaping College Readiness}

be competitive in the $21^{\text {st }}$ century workforce, including skills such as problem-solving, collaboration, adaptability, initiative, and imagination (Casner-Lotto, Barrington, \& Wright, 2006). For example, Duerden et al. (2014) found that camp experiences contributed to emerging adults' skill development in the areas of communication, problem-solving, leadership, and interpersonal skills that were aligned with $21^{\text {st }}$ century competencies.

A few researchers have examined the impact of camp participation on college-related constructs such as college aspiration, intention, and readiness. Bourdeau et al., (2014) explored the impact of a university-based science camp on perceptions of college aspiration from a group of alumni from underrepresented populations. Using standardized measures for college preparation of SAT/ACT and AP courses, the researchers found that $100 \%$ of participants planned to attend a 4-year college or university. In the aforementioned study, the researchers found that camp experiences did not increase youths' intention to attend college. Another study by Whittington and Danhof (2017) examined how camp supported nontraditional predictors of college readiness skills for female alumnae. Participants in the study reported to what extent camp affected their skill development in 12 areas related to college readiness. More than $60 \%$ of participants indicate that all 12 skills were influenced by their camp experience. Differences across these studies may be explained by the setting (i.e., university-based camps versus traditional camps), youth-staff interaction, program dosage, and other camp experience dimensions. Interest in how camp experiences may shape career readiness continues, with the American Camp Association recently committing resources to a 5-year study to examine how camp experiences support college and career readiness skills (Browne, 2016).

\section{Methods}

\section{Data Collection}

An online questionnaire was developed in Qualtrics and made available to a sample of camp directors who were identified through a collaboration with the American Camp Association (ACA), which provided a randomized list of 350 ACA-accredited camps throughout the United States. These camp directors were asked to make the questionnaire available to their camp alumni through email communications and Facebook for a 45-day period. A convenience sample of 420 alumni responded to the questionnaire. The number of camp directors who shared the questionnaire and the number of alumni who saw or responded to the advertisement is unknown, and therefore a response rate for the sampling technique could not be calculated. 


\section{Role of Camp in Shaping College Readiness}

Some questions used in this survey were adapted from scales developed by Garst, Gagnon \& Whittington (2016), which examined life skill development as reported by camp alumni.

Questions included a 4-point Likert scale which asked: "Please identify to what extent, if any, each of the following skills was impacted by your camp experience." Responses included (a) to a great extent, (b) to some extent, (c) not much extent, and (d) no extent. Questions from the self-determined behavior scale were extracted based on their relevance to college readiness skills, including: self-efficacy, confidence, and resilience. The critical thinking scale (two questions) was used in its entirety.

Other questions created by the researchers used the same Likert-type scale approach and included college readiness characteristics of independence/self-reliance, teamwork, leadership, self-regulation, communication, grit/perseverance, self-management, and time management. The final two questions included: "Did your camp experience impact your educational choices?", with a response rate of yes, no, or somewhat; and an open-ended question: "Please elaborate on how your camp experience did or did not impact your educational choices."

\section{Data Analysis}

The quantitative data were first analyzed and reported by percentages of response rates. MannWhitney $U$ tests were then conducted to compare males and females based on identified college readiness skills. The Mann-Whitney $U$ test is a rank-based nonparametric test used to assess differences between two groups on a continuous or (in this case) ordinal dependent variable (Field, 2005).

Qualitative data were analyzed using a conventional content analysis approach. Conventional content analysis is appropriate "when existing theory or research literature on a phenomenon is limited" (Hsieh \& Shannon, 2005, p. 1279). Using this approach, the data were analyzed using the following steps: data were first analyzed as a whole, and then read word for word and codes were derived. As codes emerged, notes were made about the text including any impressions about the codes. Lastly, the codes were sorted into categories. As described by Hsieh and Shannon (2005), the last step in the analysis process was to link the study findings to relevant theories and compare and contrast the study findings with those from other studies (Hsieh \& Shannon, 2005). 


\section{Role of Camp in Shaping College Readiness}

\section{Trustworthiness Procedures}

Trustworthiness techniques are used with qualitative data to validate the results of data and describe the extent to which the study findings are credible (Patton, 2002). Two steps were taken to establish the trustworthiness of the data. The first step involved the decision to collect multiple types of data to understand the same phenomenon. The survey included both qualitative and quantitative data with multiple questions related specifically to college readiness skills. The redundancy of the questions allowed the researchers to compare and contrast outcomes. The second step involved the use of multiple coders who analyzed the qualitative data independently, debriefed their findings, and reached consensus on the final themes (Bazeley, 2013; Miles \& Huberman, 1994).

\section{Results and Discussion}

\section{Demographic Descriptors}

Participants were primarily female (80\%), White (97\%), and married (56\%), with a personal income of more than $\$ 50,000$ (51\%). Participants reported their age range as: $18-24(18 \%)$, 25-34 (26\%), 35-44 (22\%), 45-54 (12\%), 55-64 (13\%), 65-74 (8\%) and 75 and over (1\%). While the participants in this study lacked diversity, these demographics are very congruent with 2016 national camper enrollment data collected by the American Camp Association, which indicated that youth campers were predominantly female, White, and representative of middleto upper-income families (Wilson, 2017).

Participants also provided descriptive information related to their camp experience. As many campers attend camp for several years and possibly at different locations the survey asked participants to think about responses in the following way: "While you may have attended many camps please answer the questions based upon the camp experience with which you most strongly affiliate." This limited respondents' choices and forced them to answer their descriptive information one way. Ninety-six percent had attended a residential camp, 4\% day camp, 67\% coed camp, $30 \%$ all-girls camp and $2 \%$ all-boys camp. The most common length of stay reported was 1 week (26\%). Most participants attended camp multiple years, with an average of 7.84 years. Participants reported having various roles: $96 \%$ attended camp as a camper, $50 \%$ as a counselor in training (CIT), $60 \%$ as a counselor and $25 \%$ as administrative staff. 
Journal of Youth Development | http://jyd.pitt.edu/ | Vol. 13 Issue 1-2 DOI 10.5195/jyd.2018.519 Role of Camp in Shaping College Readiness

\section{Camp's Impact on College Readiness Skills}

When asked, "Did your camp experience impact your educational choices?", results were fairly consistent across both males and females. Males reported $28 \%$ yes, 25\% somewhat, 47\% no. Females reported $29 \%$ yes, $21 \%$ somewhat and $50 \%$ no. These responses suggest that approximately $51 \%$ of participants felt their camp experience had an influence on their educational choice. These findings are consistent with other studies supporting the influence of the camp experience on educational choice (Bhattacharyya et al., 2011; Garst et al., 2015).

Table 1. College Readiness Skills Reported in Percentage for Women: Highest Reported to Lowest Reported ( $n=336$ )

\begin{tabular}{|l|l|l|l|l|}
\hline & \multicolumn{4}{|c|}{ Response category } \\
\hline Skill & $\begin{array}{l}\text { To a great } \\
\text { extent }\end{array}$ & $\begin{array}{l}\text { To some } \\
\text { extent }\end{array}$ & $\begin{array}{l}\text { Not much } \\
\text { extent }\end{array}$ & No extent \\
\hline Independence/self-reliance & $86 \%$ & $14 \%$ & $0 \%$ & $0 \%$ \\
\hline Teamwork & $79 \%$ & $19 \%$ & $2 \%$ & $0 \%$ \\
\hline Self-efficacy & $76 \%$ & $22 \%$ & $2 \%$ & $0 \%$ \\
\hline Confidence & $75 \%$ & $22 \%$ & $2 \%$ & $1 \%$ \\
\hline Leadership & $66 \%$ & $29 \%$ & $5 \%$ & $1 \%$ \\
\hline Self-regulation & $65 \%$ & $27 \%$ & $7 \%$ & $1 \%$ \\
\hline Communication & $64 \%$ & $31 \%$ & $5 \%$ & $0 \%$ \\
\hline Resilience & $62 \%$ & $34 \%$ & $4 \%$ & $0 \%$ \\
\hline Grit/perseverance & $61 \%$ & $30 \%$ & $9 \%$ & $0 \%$ \\
\hline Self-management & $59 \%$ & $31 \%$ & $9 \%$ & $1 \%$ \\
\hline Problem solving & $53 \%$ & $36 \%$ & $9 \%$ & $1 \%$ \\
\hline Time management & $46 \%$ & $35 \%$ & $1 \% \%$ \\
\hline Critical thinking & $40 \%$ & $4 \%$ & $2 \%$ \\
\hline
\end{tabular}

Participants were asked, "Please identify to what extent, if any, each of the following skills was impacted by your camp experience." College readiness skills were ordered according to what 
Journal of Youth Development | http://jyd.pitt.edu/ | Vol. 13 Issue 1-2 DOI 10.5195/jyd.2018.519 Role of Camp in Shaping College Readiness

percentages of respondents reported them as having been greatly impacted by their camp experience and are shown in Table 1 (women) and Table 2 (men). For all skill areas both males and females reported that camp did have an impact on their skills "to a great extent" or "to some extent" with very few reporting "no extent" (between $1 \%$ and $4 \%$ ). In all skill areas except problem solving, teamwork, and critical thinking, a higher percentage of women than men reported camp having an impact on their skill development "to a great extent."

Table 2. College Readiness Skills Reported in Percentage for Men: Highest Reported to Lowest Reported $(n=84)$

\begin{tabular}{|l|l|l|l|l|}
\hline & \multicolumn{4}{|c|}{ Response category } \\
\hline Skill & $\begin{array}{l}\text { To a great } \\
\text { extent }\end{array}$ & $\begin{array}{l}\text { To some } \\
\text { extent }\end{array}$ & $\begin{array}{l}\text { Not much } \\
\text { extent }\end{array}$ & No extent \\
\hline Teamwork & $80 \%$ & $17 \%$ & $4 \%$ & $0 \%$ \\
\hline Independence/self-eliance & $76 \%$ & $21 \%$ & $2 \%$ & $0 \%$ \\
\hline Self-efficacy & $71 \%$ & $23 \%$ & $6 \%$ & $0 \%$ \\
\hline Confidence & $71 \%$ & $23 \%$ & $2 \%$ & $0 \%$ \\
\hline Leadership & $63 \%$ & $27 \%$ & $10 \%$ & $0 \%$ \\
\hline Communication & $62 \%$ & $31 \%$ & $7 \%$ & $0 \%$ \\
\hline Self-regulation & $59 \%$ & $29 \%$ & $9 \%$ & $2 \%$ \\
\hline Resilience & $56 \%$ & $38 \%$ & $6 \%$ & $0 \%$ \\
\hline Grit/perseverance & $55 \%$ & $36 \%$ & $8 \%$ & $1 \%$ \\
\hline Problem solving & $54 \%$ & $29 \%$ & $15 \%$ & $2 \%$ \\
\hline Self-management & $53 \%$ & $29 \%$ & $16 \%$ & $2 \%$ \\
\hline Critical thinking & $44 \%$ & $33 \%$ & $4 \%$ & \\
\hline Time management & $36 \%$ & & $21 \%$ & \\
\hline
\end{tabular}

There were similarities between men and women in terms of the skills they most often and least often reported as having been influenced by camp. The three skills reported most frequently as having been impacted by camp were independence/self-reliance, teamwork, and 
Journal of Youth Development | http://jyd.pitt.edu/ | Vol. 13 Issue 1-2 DOI 10.5195/jyd.2018.519 Role of Camp in Shaping College Readiness

self-efficacy; men reported teamwork most frequently and women reported independence/selfreliance most frequently. Time management and critical thinking were the two skills reported by the lowest percentages of men and women as having been impacted by camp experience, with the lowest percentage of men reporting time management, and the lowest percentage of women reporting critical thinking. Even these skills, however, were reported as having been greatly or somewhat impacted by camp by at least three quarters of men and women.

Table 3. Mann-Whitney U Comparisons for Gender and College Readiness Skills

\begin{tabular}{|l|l|l|l|l|}
\hline & Males $(\boldsymbol{n}=\mathbf{8 4})$ & Females $(\boldsymbol{n}=\mathbf{3 3 6})$ & \\
\hline College readiness Skills & Mean rank & Mean rank & $\boldsymbol{U}$ & $\boldsymbol{p}$ \\
\hline Independence/self-reliance & 194.05 & 214.61 & 12730.0 & $.030 *$ \\
\hline Time management & 191.07 & 214.13 & 12480.0 & .093 \\
\hline Self-management & 193.60 & 213.44 & 12582.5 & .128 \\
\hline Self-regulation & 197.68 & 213.75 & 13147.5 & .197 \\
\hline Resilience & 199.77 & 213.18 & 13211.0 & .291 \\
\hline Grit/perseverance & 198.42 & 211.05 & 13097.0 & .322 \\
\hline Self-efficacy & 201.38 & 212.16 & 13345.5 & .333 \\
\hline Confidence & 204.58 & 212.62 & 13734.5 & .476 \\
\hline Leadership & 203.94 & 212.14 & 13561.0 & .508 \\
\hline Problem solving & 204.46 & 211.39 & 13604.5 & .601 \\
\hline Communication & 204.02 & 209.63 & 13568.0 & .651 \\
\hline Critical thinking & 210.47 & 209.26 & 13946.5 & .929 \\
\hline Teamwork & 209.64 & 209.46 & 13890.5 & .986 \\
\hline P & & &
\end{tabular}

${ }^{*} p<.05$

Mann-Whitney $U$ tests were conducted to determine if any differences between men and women existed in reported college readiness skills between male and female participants (Table 3). Independence/self-reliance scores were statistically significantly higher for females than for males $(p=.030)$. (A small effect size was calculated, $r=.10$.). This finding supports prior 


\section{Role of Camp in Shaping College Readiness}

research on how female camp participants gained independence as an outcome of their participation. For example, Whittington, Garst, Gagnon and Baughman, (2017) examined outcomes of female participants experience at camp and found that participants gained selfreliance and independence through their participation.

\section{Camp's Influence on Academic Pursuits}

When asked to "please elaborate on how your camp experience did or did not impact your educational choices," $53 \%$ of participants provided a response ( $19 \%$ male; $81 \%$ female). The data were analyzed based on gender but no differences were observed. Because of this finding, the data were reported collectively. Three major themes developed from the analysis of the qualitative data, which included how camp: (1) shapes academic interests, (2) influences location of academic study, and (3) facilitates motivation to achieve. Several participants expressed a dissenting voice and how camp did not influence their education choices.

Camp Shapes Academic Interests. Participants (35\%) in this study described how camp influenced their academic interests and pursuits in a variety of ways. This influence included changing the subject matter they wanted to study and encouraging the pursuit of a specific degree. Participants most often identified camp administration or nature/science as areas of study influenced by their camp involvement. One male respondent stated: "I changed my major to include something more relevant to the camping (and conference center) industry, and my electives were all based more on recreation and outdoor education." Another male stated:

[I] was in chemical engineer studies, began working at camp in the summer, switched to education, got my teaching degree, taught for four years while still working at camp in the summer and then the opportunity came along to make this a career. I left teaching and became a camp director full time.

In the next quote, a female respondent described how camp and the camp administrative staff influenced her program of study:

My senior year of high school I asked my camp director what major I needed to be a camp director. He said business. I followed his suggestion. Half way through I had an English teacher that read my paper on why my CIT experience was an impact on my life. He suggested I major in Recreation. I changed majors and then after finishing, went back and finished the 
Journal of Youth Development | http://jyd.pitt.edu/ | Vol. 13 Issue 1-2 DOI 10.5195/jyd.2018.519

\section{Role of Camp in Shaping College Readiness}

business degree the next year. Later I went to graduate school for Recreation Administration. In that degree I wrote a paper on Spirituality in Organized Camping and that paper prepared me for Seminary. My camp director was a minister. Camp did me a world of good and still does.

Another area of academic pursuit heavily influenced by the camp experience included nature/science degrees. One male reported: "Looking up at the stars drove me to study Astronomy", and a female respondent stated: "I have a Masters in Outdoor and Environmental Education-this was mostly impacted by my camp experiences". One female participant wrote:

I chose to study environmental science after flirting with the idea of theater when I was younger. The relationship I cultivated with nature through my many camping and backpacking experiences brought me to study the environment. For my master's I studied holistic psychology and focused on adolescents and the effectiveness of alternative therapies like nature, art and meditation for adolescents- the sorts of experiences gained through camp.

This study supports previous literature about the role that camp experiences play in influencing future college choices and decisions (Bhattacharyya et al., 2011; Brandt \& Arnold, 2006). But as previously noted, not all studies have found that camp necessarily increases a child's plans for attending college (Bhattacharyya et al., 2011), which may reflect the limitations associated with brief enrichment experiences such as one week of camp when questions about camp's potential influence on college choices are asked immediately following camp. In retrospective studies camp participants have a much longer period of time on which to reflect.

Camp Influences Location of Academic Study. Participants (16\%) described how camp impacted where they chose to study. This choice was influenced by peers, the location of the school (closer to camp), and choosing a school that fostered a culture similar to their camp. Often it was a combination of more than one factor as illustrated by the quote by a female respondent: "I chose a college less than an hour from my sleepaway camp and two hours from my best camp friend." Another female stated: "I went to school in a location with a lot of access to the outdoors...also where a lot of my camp friends were." 


\section{Role of Camp in Shaping College Readiness}

Some participants shared how they choose a college or university based on an environment that was similar to their camp or even in the same state or close proximity to camp. One female stated: "I went away for college in a rural area like camp" and another female stated: "I chose a school that I could easily access camp from. I made sure I could still be able to attend camp if I chose the school I did, because all the relationships I've made there are so important to me."

Other participants described how they choose a college that mimicked the culture of their camp and provided some of the same experiences. One female responded stated: "I sought out the same sense of community as I felt at camp when choosing a college." A male participant wrote:

I chose to attend a small liberal arts school that prioritizes relationships, accountability, and fosters a cooperative and collaborative community as part of its institutional culture. It also has a strong wilderness education program which resonated strongly with [Camp Name] programs.

Another female stated:

I enjoyed being part of a small, close-knit community at my camp. I knew I wanted a college that fostered small communities within the large community. I knew I wanted a college that supported women's leadership and activities. The University of [Name] provided me with both, and my time at camp prepared me well for my college years.

Participant responses about "location" reflect the importance of place and belonging that come to be associated with camp over time, and that participants wanted to replicate in their future college choice. These findings are supported by Genson (2010), who studied place attachment within camp settings and noted that "strong attachments to relationships in that environment ... led to participants becoming attached to the physical location of the camp" (p. 72). It may be that the familiarity and belongingness that youth feel toward camp buffer stressful life events such as a transition to college. This proposition is supported by the findings in this study, in which people were highly motivated to remain geographically close to people they built relationships with at camp.

Camp Facilitates Motivation to Achieve. Participants (11\%) in this study reported that camp motivated them in a variety of ways. Camp made participants more focused, goal-directed and increased their desire to succeed. As one female participant stated, "I probably would have 
Journal of Youth Development | http://jyd.pitt.edu/ | Vol. 13 Issue 1-2 DOI 10.5195/jyd.2018.519

\section{Role of Camp in Shaping College Readiness}

dropped out of high school if not motivated to get to camp that summer. Then seeing everyone I looked up to going to college."

For others, camp participation provided the motivation to attend college despite social influences telling them otherwise, and also provided increased participants' confidence that enabled them to pursue higher education. For example, one female participant shared that camp "made me empowered to decide I would finish college and pursue a career no matter what. At a time when most girls (the 60s) were assumed to just want to marry and have a family after high school." Another female participant reflected:

Neither of my parents attended college and in my extended family it was not the norm. I believe that going away to camp gave me the confidence to know I could go away from home and attend college in another state.

Some participants described how camp allowed them to gain skills and offered opportunities to develop perseverance that supported their success. One female reported, "While my educational path was not directly influenced by camp, the skills I learned (confidence, leadership, perseverance) kept me going in my chosen field despite setbacks." A male participant reported, "I always strived to be the best and that comes directly from camp, where I always wanted to be the best, try the hardest, and help all of those in need."

Motivation to achieve has not received extensive attention within the camp literature. However, using the frame of expectancy-value theory (Atkinson, 1957), Genson (2010) suggested that camp influenced future choices for career and college because of how it changes a camp participant's perception of the usefulness of the experience. In short, camp participants come to see the camp experience as particularly valuable, because they better understand how camp experiences fit into their future plans (Wigfield \& Eccles, 2000). Again, findings such as these may be salient in retrospective studies in which participants can reflect on the relative value of camp experiences (in this case, for influencing college decisions) when compared to other life experiences.

Dissenting Voice. As previously noted, not all participants felt that camp participation influenced their educational choices. Several participants (23\%) expressed that camp had no influence on their educational choices. One female stated: "It had no effect" and another female stated "No impact ... No, there was nothing I 'chose' because of camp" and "I would have gone to college no matter what". Others were more emphatic in stating that camp did not influence decision- 


\section{Role of Camp in Shaping College Readiness}

making regarding their educational choices. One female wrote: "It wasn't a consideration, when I chose my college and degree" and "I was already set on my desire for higher education, but my experience [at camp] didn't affect what I chose to study or where I went to college." Other comments included a concern that camp and school should be two separate entities and that camp should focus on fun, not on academics.

\section{Implications}

Findings from this study suggest that camp experiences facilitate a wide range of college readiness skills. These results build on prior research about the influence of camp experiences on college choice and aspirations (Bordeau et al., 2014) by identifying how camp might help prepare a young person for college success. What Garst et al. (2015) noted about career readiness via camp experiences might also be true about college readiness; although college readiness may not be a targeted outcome for many camps, it may be an indirect outcome of camp involvement.

Camp participation may be particularly important for influencing college readiness for women. As previously noted, although women may have a "female advantage" when it comes to some dimensions of academic performance (Cogner \& Long, 2010; Riegle-Crumb, 2010), research also suggests that women may lack confidence in their academic capabilities (Sax, 2007) and are less likely than men to pursue a career in a STEM field (Klevan et al., 2016). The results of this study suggest that camp was influential in building skills such as independence, selfefficacy, and confidence in women. Furthermore, respondents in this study provided insight into how camp might provide male and female youth with a portal to STEM fields through nature/science exploration. These findings suggest the important role that camps could play in encouraging college readiness through more intentional programming, such as inviting camp staff to openly talk with campers about their relevant college academic experiences as well as linking specific camp activities to academic areas (e.g., associating nature hikes to environmental science, kayaking to recreation and hydrology, archery with physics and math).

The role of camp in shaping where camp participants choose to pursue academic study is compelling, as it supports the way in which people become attached to particular places through the development of emotional, behavioral, and even geographical bonds with those places (Eisenhauer, Krannich, \& Blahna, 2000), and how they may frequently return to special places over time (Genson, 2010; Reid \& Palechuk, 2017). By building strong relationships with local colleges and universities, camps can become recognized by institutions of higher education 


\section{Role of Camp in Shaping College Readiness}

as a strategic pathway (and vital asset) for encouraging young people to attend a college or university, and not just any college or university, but rather the college and university geographically located near their special camp place.

This study provides a good starting point for further examination of the development of college readiness skills through camp experiences. However, a wide range of skills relevant for college readiness have yet to be examined within the camp experience. For example, Lippman, Atlenza, Rivers, and Keith (2008) proposed that:

College readiness criteria could be expanded to include healthy

behaviors, avoiding risky behaviors, positive mental health,

resilience, a strong work ethic and moral character, social

competence, and creativity. The addition of these attributes would

help youth prepare to optimize their success, healthy

development, and experience in both college and the workplace

(p. 5).

Future studies of college readiness and camp should consider the potential influence of camp experiences on this broader range of skills.

\section{Limitations}

Several potential limitations are acknowledged: (a) the sample lacked diversity and was homogeneous (i.e., primarily middle-to-upper-income White women and men), however, it is consistent with the current demographics of who is attending camp (Wilson, 2017); (b) the study design and sampling approach did not allow for participants to be closely tracked, so the representativeness of the sample could not be determined; and (c) characteristic weaknesses in the use of self-report in retrospective designs (Lamb, 2005), such as the influence of intellectual inferencing (Grove, Bunning, Porter, \& Olsson, 1999) and effort justification (Taylor, Russ-Eft, \& Taylor, 2009), may have biased participant responses. Additional trustworthiness techniques, including respondent validation (Maxwell, 2013), would have allowed another way to affirm the accuracy of the study findings.

\section{Conclusion}

High school transcripts, grade point averages, and standardized test scores are not the only predictors of academic achievement in post-secondary education. Students also need a variety 


\section{Role of Camp in Shaping College Readiness}

of skills to support college readiness (Arnold et al., 2012; Nelson, 2012). These skills can be taught and practiced outside of the traditional classroom in settings such as camp. This study suggests that camp can build a pathway to the future success of campers' pursuit of secondary education by offering them the opportunity to develop, practice and gain college readiness skills.

This study contributes to our maturing understanding of how camp impacts and influences lives by concurring and validating previous literature (Bhattacharyya et al., 2011; Brandt \& Arnold, 2006; Garst, Franz, Baughman, Smith \& Peters, 2009; Genson, 2010; Wigfield \& Eccles, 2000; Whittington \& Danhof, 2017). New findings from this study add to the growing body of research on how camp supports college and career readiness (Browne, 2016). Through this study we examined the college readiness skills that were most influenced by camp participation, explored gender differences in received outcomes, and shared both the supporting and dissenting views of how camp affects college readiness.

Camp practitioners should engage their current stakeholders (e.g., parents, alumni, future campers) as well as begin outreach to local colleges and universities to promote the role of camp experiences in shaping college aspiration, intention, and readiness. While preparing their middle and high school-aged children for the future, parents should understand the role that camp experiences can play in the overall mix of opportunities that promote future success. Findings such as these can empower practitioners to better articulate how camp is a natural pathway toward successful adulthood. Questions used in this study could be used by camp directors to generate camp-specific data from their own campers and staff. At the end of the day, we hope this study helps camp professionals tell a strong story about the role of camp in shaping future college interest in the girls and boys that come to camp.

\section{References}

Allen, J., Robbins, S. B., \& Sawyer, R. (2010). Can measuring psychosocial factors promote college success? Applied Measurement in Education, 23, 1-22.

Arnold, K. D., Lu, E. C., \& Armstrong, K. J. (2012). The ecology of college readiness. ASHE Higher Education Report, 38(5), Wiley Periodicals, p. 1-138.

Atkinson, J. W. (1957). Motivational determinants of risk-taking behavior. Psychological Review, 64, 359372. Retrieved from http://psycnet.apa.org/journals/rev/64/6p1/359.pdf

Bazeley, P. (2013). Qualitative data analysis: Practical strategies. Washington DC: Sage. 
Journal of Youth Development | http://jyd.pitt.edu/ | Vol. 13 Issue 1-2 DOI 10.5195/jyd.2018.519

\section{Role of Camp in Shaping College Readiness}

Bhattacharyya, S., Mead, T. P., \& Nathaniel, R. (2011). The influence of science summer camp on African-American high school students' career choices. School Science and Mathematics, 111(7), 345-353.

Bialeschki, M. D., Henderson, K. A., \& James, P. A. (2007). Camp experiences and development outcomes for youth. Child and Adolescent Psychiatric Clinics of North America, 16, 769-788.

Bourdeau, V. S., Galloway, R., Arnold, M., \& Nott, B. D. (2014). Impact of a middle school 4-H science camp on college aspirations of alumni. Journal of Extension, 52(1). Retrieved from https://www.joe.org/joe/2014february/a4.php

Brandt, J., \& Arnold, M. A. (2006). Looking back, the impact of the 4-H camp counselor experience on youth development: A survey of counselor alumni. Journal of Extension, 44(6). Retrieved from www.joe.org/ joe/2006december/rb1.shtml

Browne, L. (2016). Research 360: The cast of characters, Part 2 [Blog post]. Retrieved from http://www.acacamps.org/news-publications/blogs/research-360/research-360-cast-characterspart-2

Buchmann, C., DiPrete, T. A., \& McDaniel, A. (2008). Gender inequalities in education. Annual Review of Sociology 34, 319-337.

Casner-Lotto, J., Barrington, L., \& Wright, M. (2006). Are they really ready to work?:Employers' perspectives on the basic knowledge and applied skills of new entrants to the $21^{\text {st }}$ century U.S. workforce. Conference Board, Inc., the Partnership for $21^{\text {st }}$ Century Skills, Corporate Voices for Working Families, and the Society for Human Resource Management.

Cogner, D., \& Long, M. C. (2010). Why are men falling behind? Gender gaps in college performance and persistence. Annals, American Academy of Political and Social Science, 627, 184-214.

Conley, D. T. (2007). Redefining college readiness (Vol. 3). Eugene, OR: Educational Policy Involvement Center.

Conley, D. T. (2008). Rethinking college readiness. New Directions for Higher Education (no. 144), Wiley Periodicals. DOI: $10.1002 /$ he.321

Conley, D. T. (2010). College and career ready. San Francisco, CA: Jossey-Bass.

Conley, D. T. (2014). Getting ready for college and career readiness. Eugene, OR: Educational Policy Improvement Center.

Conley, D. T., \& French, E. M. (2014). Student ownership of learning as a key component of college readiness. American Behavioral Scientist, 58(8), 1018-1034.

Corbett, C., \& Hill, C. (2012). Graduating to a pay gap: The earnings of men and women one year after college graduation. Washington, DC: American Association of University

Women. Retrieved from https://www.aauw.org/files/2013/02/graduating-to-a-pay-gap-the-earnings-ofwomen-and-men-one-year-after-college-graduation.pdf 
Journal of Youth Development | http://jyd.pitt.edu/ | Vol. 13 Issue 1-2 DOI 10.5195/jyd.2018.519

\section{Role of Camp in Shaping College Readiness}

Digby, J. K., \& Ferrari, T. M. (2007). Camp counseling and the development and transfer of workforce skills: The perspective of Ohio 4-H camp counselor alumni. Journal of Youth Development, 2(2), 103-122.

Duerden, M., Witt, P., Garst, B., Bialeschki, D., Schwarzlose, T., \& Norton, K. (2014). The impact of camp employment on the workforce development of emerging adults. Journal of Park and Recreation Administration, 32(1), 26-44.

Eaton, C. K., LaMotte, J., Gutierrez-Colina, A. M., Kardon, P., \& Blount, R. L. (2016). Changes in socioemotional and behavioral functioning after attending a camp for children with Tourette Syndrome: A preliminary investigation. Journal of Abnormal Child Psychology, 44(6), 1197-1203.

Eisenhauer, B. W., Krannich, R. S., \& Blahna, D. J. (2000). Attachments to special places on public lands: An analysis of activities, reason for attachments, and community connections. Society \& Natural Resources, 13(5), 421-441.

Field, A. (2005). Discovering statistics using SPSS ( $2^{\text {nd }}$ ed). Thousand Oaks, CA: Sage.

Gaertner, M. N, \& McClarty, K. L. (2015). Performance, perseverance, and the full picture of college readiness. Educational Measurement: Issues and Practice, 34(2), 20-33.

Garst, B., Baughman, S., Whittington, A., \& Gagnon, R. J. (2015). Influences of resident camp experiences on career choice: A case study of female alumnae. Research in Outdoor Education, 13(1), 59-82.

Garst, B. A., Browne, L., \& Bialeschki, M. D. (2011). Youth development and the camp experience. New Directions for Youth Development, 130, 73-88. https://doi.org/10.1002/yd.398

Garst, B., Franz, N. Baughman, S., Smith, C., \& Peters, B. (2009). Growing without limitations: Transformation among young adult camp staff. Journal of Youth Development, 4(1), 21-34.

Garst, B. A., Gagnon, R. J., \& Whittington, A. (2016). A closer look at the camp experience: Examining relationships between life skills, elements of positive youth development, and antecedents of change among camp alumni. Journal of Outdoor Recreation, Education, and Leadership, 8(2), 180-199. https://doi.org/10.18666/JOREL-2016-V8-I2-7694

Garst, B., \& Johnson, J. (2005). Adolescent leadership skill development through residential camp counseling. Journal of Extension, 43(5). Retrieved from www.joe.org/joe/2005october/rb5.php

Genson, J. M. (2010). Examining the interrelationship of motivation and place attachment in a residential 4-H camping environment. (Unpublished master's thesis). Virginia Polytechnic Institute and State University, Blacksburg, VA.

Grove, N., Bunning, K., Porter, J., \& Olsson, C. (1999). See what I mean: Interpreting the meaning of communication by people with severe and profound intellectual disabilities.Journal of Applied Research in Intellectual Disabilities, 12, 190 - 203.

Hsieh, H. F., \& Shannon, S. E. (2005). Three approaches to qualitative content analysis. Qualitative Health Research, 15(9), 1277-1288. 
Journal of Youth Development | http://jyd.pitt.edu/ | Vol. 13 Issue 1-2 DOI 10.5195/jyd.2018.519

\section{Role of Camp in Shaping College Readiness}

Kirk, R., \& Day, A. (2011). Increasing college access for youth aging out of foster care: Evaluation of a summer camp program for foster youth transitioning from high school to college. Children and Youth Services Review, 33(7), 1173-1180.

Klevan, S., Weinberg, S. L., \& Middleton, J. A. (2016). Why are the boys missing: Using social capital to explain gender differences in college enrollment for public high school students. Research in Higher Education, 57, 223-257. doi: 10.1007/s11162-015-9384-9

Lamb, T. (2005). The retrospective pretest: An imperfect but useful tool. The evaluation exchange, 11(2), 18-19.

Lippman, L., Atlenza, A., Rivers, A., \& Keith, J. (2008). A developmental perspective on college and workplace readiness. Washington, D.C.: Child Trends.

Maxwell, J. A. (2013). Qualitative research design: An interactive approach (3rd ed.). Sage.

Miles, M. B., \& Huberman, A. M. (1994). An expanded sourcebook: Qualitative data analysis. Thousand Oaks, CA: Sage.

Mueller, J. (2009). Assessing critical skills. Columbus, OH: Linworth.

Nelson, V. (2012). Soft skills, strong success: Fifteen skills for college readiness. Retrieved from https://www.collegeparentcentral.com/2011/12/soft-skills-strong-readiness-fifteen-skills-yourstudent-needs-to-be-college-ready $/$

Patton, M. Q. (2002). Qualitative research and evaluation methods ( $3^{r d}$ ed.). Thousand Oaks, CA: Sage.

Reid, R., \& Palechuk, T. (2017). Place relationships in a wilderness setting: an analysis of two mountaineering camps in the Canadian Rocky Mountains. Leisure/Loisir, 41(2), 185-204.

Reigle-Crumb, C. (2010). More girls go to college: Exploring the social and academic factors behind the female postsecondary advantage among Hispanic and white students. Research in Higher Education, 51(6), 573-593.

Sax, L. J. (2007). College women still face many obstacles in reaching their full potential. The Chronicle of Higher Education, 54(5). Retrieved from https://www.chronicle.com/article/College-Women-StillFace-Many/33633

Savitz-Romer, M., \& Bouffard, S. M. (2012). Ready, willing and able: A developmental approach to college access and success. Cambridge, MA: Harvard Education Press.

Taylor, P. J., Russ-Eft, D. F., \& Taylor, H. (2009). Gilding the outcome by tarnishing the past: Inflationary biases in retrospective pretests. American Journal of Evaluation, 30(1), 31-43.

Tierney, W. G., \& Sablan, J. R. (2014). Examining college readiness. American Behavioral Scientist 58(8), 943-946.

Whittington, A., \& Danhof, J. (2017). Developing college readiness skills at camp. 2017 American Camp Association Research Abstracts (pp. 48-50). Retrieved from http://www.acacamps.org/sites/default/files/resource library/2017 ACA Book of Abstracts.pdf 
Journal of Youth Development | http://jyd.pitt.edu/ | Vol. 13 Issue 1-2 DOI 10.5195/jyd.2018.519 Role of Camp in Shaping College Readiness

Whittington, A., Garst, B. A., Gagnon, R. J., \& Baughman, S. (2017). Living without boys: A retrospective analysis of the benefits and skills gained at all-female camps. Journal of Experiential Education, 4O(2), 97-113. doi. 10.1177/1053825916689266

Wigfield, A., \& Eccles, J. S. (2000). Expectancy-value theory of achievement motivation. Contemporary Educational Psychology, 25, 68-81.

Wilson, C. (March/April, 2017). 2016 camper enrollment: With strong enrollment comes new challenges. Camping Magazine, p. 64-66. Retrieved from http://www.acacamps.org/resourcelibrary/camping-magazine/2016-camper-enrollment-strong-enrollment-comes-new-challenges 